\title{
Kemampuan representasi matematis siswa SMP melalui pendekatan pendidikan matematika realistik
}

\author{
Sulastri, Marwan ${ }^{1}$, M. Duskri
}

\begin{abstract}
Abstrak: Penelitian kualitatif ini bertujuan untuk mendeskripsikan kemampuan representasi matematis siswa melalui pendekatan Pendidikan Matematika Realistik (PMR). Penelitian ini dilakukan di kelas VII-2 SMP Negeri 6 Banda Aceh yang melibatkan enam siswa. Kemampuan representasi siswa dianalisis dari hasil tes dan wawancara setelah penerapan PMR melalui tahap reduksi data, penyajian data, dan penarikan kesimpulan. Berdasarkan hasil tes, subjek penelitian dikategorikan menjadi siswa dengan kemampuan representasi matematika tinggi, sedang dan rendah. Keenam siswa tersebut diwawancara untuk mengonfirmasi hasil tes. Hasil penelitian menunjukan bahwa siswa yang berkemampuan tinggi dan sedang memenuhi ketiga indikator kemampuan representasi matematis yaitu menyajikan data atau informasi dari suatu masalah ke representasi tabel, menyelesaikan masalah yang melibatkan ekspresi matematis, serta menuliskan langkah-langkah penyelesaian masalah matematika dengan kata-kata. Siswa berkemampuan rendah memenuhi dua indikator kemampuan representasi matematis yaitu menyelesaikan masalah yang melibatkan ekspresi matematis dan menuliskan langkahlangkah penyelesaian masalah matematika dengan kata-kata.
\end{abstract}

Kata kunci: Representasi Matematis; Kemampuan; Pendidikan Matematika Realistik

Abstract: This qualitative reseach aims at describing students' representation ability through realistic mathematics education (RME). It is conducted in grade VII-2 SMP Negeri 6 Banda Aceh focusing on the six students. Students' representation ability is analyzed from the developed test and interview after applying RME through data reduction, data display and conclusion. Based on the result of the test, the subjects are categorized into students who have high, medium and

\footnotetext{
${ }^{1}$ Universitas Syiah Kuala, Aceh, Indonesia, sulastrirusmani@gmail.com

${ }^{2}$ Universitas Islam Negeri Ar-Raniry, Aceh, Indonesia
} 
low ability in mathematical representation. They are then interviewed to confirm the test. The research finds that students in high and medium category fulfill the three indicators of mathematical representation, i.e. displaying data or information of a problem into table, solving problems that involve mathematical expression, and write the steps in solving the problems using words. Meanwhile, students in low category can only fulfill the second and third indicator.

Keywords: Mathematics Representation; Ability; RME

\section{A. Pendahuluan}

Salah satu kemampuan yang dituntut dalam pembelajaran matematika adalah kemampuan representasi matematis (NCTM, 2000). Menurut NCTM (2000), representasi merupakan translasi suatu masalah atau ide dalam bentuk baru, termasuk di dalamnya dari gambar atau model fisik ke dalam bentuk simbol, kata-kata atau kalimat. Dahlan (2011) menambahkan bahwa representasi merupakan dasar atau fondasi bagaimana seorang siswa dapat memahami dan menggunakan ide-ide matematika. Representasi berkaitan dengan dua hal, yaitu proses dan produk.

Salah satu materi yang dipelajari siswa kelas VII SMP adalah Persamaan Linear Satu Variabel (PLSV), Pertidaksamaan Linear Satu Variabel (PtLSV), serta perbandingan. Aplikasi materi tersebut dapat berupa persoalan sehari-hari, sehingga memerlukan kemampuan representasi yang baik dalam menyelesaikan permasalahan yang diberikan. Akan tetapi, berdasarkan penelitian awal oleh peneliti, ketika siswa mengerjakan soal, siswa kesulitan dalam merepresentasikan suatu masalah nyata. Siswa memiliki kesulitan merepresentasikan soal cerita ke dalam bentuk model matematika, kurang memahami konsep dasar mengenai PLSV, PtLSV dan perbandingan. Mereka sulit menafsirkan soal, membedakan apakah soal yang diberikan merupakan konsep PLSV atau PtLSV, membedakan apakah soal yang diberikan merupakan konsep perbandingan senilai atau perbandingan berbalik nilai. Hal ini dikarenakan siswa jarang menggunakan representasi gambar, tabel dan model matematika untuk membantunya berpikir dalam menyelesaikan soal. 
Dengan demikian, representasi belum digunakan sebagai alat untuk berpikir dan memecahkan soal. Hal ini mengindikasikan bahwa kemampuan representasi matematis siswa masih kurang.

Beberapa penelitian yang telah dilakukan menjelaskan mengenai kesalahan-kesalahan yang dilakukan siswa dalam kemampuan representasi. Legi (2008) menyatakan bahwa siswa dengan kemampuan rendah, kesulitan dalam menciptakan dan menggunakan representasi simbolik dan gambar. Selain itu, Suryowati (2015) juga mengungkapkan bahwa siswa masih belum memahami bagaimana merepresentasikan masalah dunia nyata ke dalam masalah matematika yang representatif. Dua penelitian tersebut (Legi, 2008; Suryowati, 2015) merekomendasikan upaya yang dapat dilakukan guru agar siswa memiliki kemampuan representasi dengan memilih dan menggunakan pendekatan pembelajaran yang tepat, sehingga proses pembelajaran berlangsung optimal dan mampu mengembangkan kemampuan representasi matematis.

Salah satu alternatif untuk meningkatkan kemampuan representasi matematis siswa adalah melalui pendekatan Pendidikan Matematika Realistik (PMR). Memulai pembelajaran dengan mengajukan masalah yang sesuai dengan pengalaman dan tingkat pengetahuan siswa merupakan salah satu ciri PMR. Melalui PMR diharapkan siswa mampu mengembangkan kemampuan representasi matematis karena melalui materi yang diberikan dan disertai dengan pemberian contoh matematika yang bersumber dari kondisi kehidupan sehari-hari siswa dapat merepresentasikan soal dengan lebih baik dan sederhana. Pembelajaran dengan PMR dimulai dari sesuatu yang riil sehingga siswa dapat terlibat dalam pelajaran secara bermakna (Hadi, 2017).

Pendekatan PMR merupakan salah satu pendekatan pembelajaran yang dapat digunakan untuk meningkatkan kemampuan representasi matematis siswa. Kohar (2012) menyatakan melalui pembelajaran volume balok dan kubus dengan pendekatan PMR dapat membantu siswa dalam merepresentasikan masalah matematis. Selanjutnya Legi (2008) menyatakan pembelajaran melalui PMR dapat membelajarkan siswa menciptakan dan menggunakan representasi matematis. Soedjadi (2007) menyebutkan bahwa PMR mempunyai karakteristik menggunakan model, artinya permasalahan atau ide dalam matematika dapat dinyatakan dalam bentuk 
model, baik model dari situasi nyata maupun model yang mengarah ketingkat abstrak.

Mempertimbangkan kemampuan representasi matematika siswa yang masih rendah dan karakteristik PMR yang mendukung siswa dalam mengembangkan kemampuan representasi, penelitian ini akan menjawab pertanyaan, bagaimanakah kemampuan representasi matematis siswa SMP melalui pendekatan Pendidikan Matematika Realistik?

\section{B. Metode Penelitian}

Pendekatan yang dilakukan pada penelitian ini adalah pendekatan kualitatif. Penelitian ini bertujuan untuk mengetahui kemampuan representasi matematis siswa setelah diterapkan pendekatan Pendidikan Matematika Realistik. Subjek dalam penelitian ini adalah siswa kelas VII-2 SMP Negeri 6 Banda Aceh tahun ajaran 2016/2017 yang terdiri dari enam orang siswa kemudian dikelompokan menjadi dua siswa yang memiliki kemampuan rendah, dua siswa yang memiliki kemampuan sedang dan dua siswa yang memiliki kemampuan tinggi berdasarkan tes kemampuan representasi setelah diterapkan PMR. Pengelompokan ini dilakukan untuk mengetahui capaian kemampuan representasi matematis siswa berdasarkan indikator pada Tabel 1 .

Instrumen dalam penelitian ini berupa lembar tes dan wawancara. Instrumen tersebut divalidasi oleh para pakar, yaitu dua orang ahli dalam bidang PMR yang merupakan dosen pendidikan Matematika Unsyiah dan satu orang guru matematika (anggota dari P4MRI) yang mengajar di SMP Negeri 1 Banda Aceh. Lembar tes digunakan untuk memperoleh data tentang kemampuan representasi matematis siswa pada materi PLSV, PtLSV, dan perbandingan setelah proses belajar melalui PMR. Data penelitian diperoleh dari hasil tes yang berkaitan dengan kemampuan representasi matematis siswa pada materi PLSV, PtLSV, dan perbandingan. Tujuan wawancara adalah untuk mendapatkan data yang lebih akurat dan jelas dari subjek penelitian tentang kemampuan representasi matematis.

Pembelajaran dilakukan sebanyak lima kali pertemuan yang berlangsung dengan menggunakan pendekatan PMR. Kemampuan representasi matematis siswa melalui PMR dinilai berdasarkan kriteria pada Tabel 1. 
Tabel 1. Pedoman Penskoran Kemampuan Representasi Matematis

\begin{tabular}{|c|c|c|}
\hline Aspek yang Dinilai & $\begin{array}{c}\text { Respon Siswa terhadap } \\
\text { Soal/Masalah }\end{array}$ & Skor \\
\hline $\begin{array}{l}\text { Menyajikan data atau } \\
\text { informasi dari suatu } \\
\text { masalah ke representasi } \\
\text { gambar, diagram, grafik } \\
\text { atau tabel }\end{array}$ & $\begin{array}{l}\text { a. Data atau informasi yang dapat } \\
\text { disajikan ke representasi } \\
\text { gambar, diagram, grafik, atau } \\
\text { tabel salah } \\
\text { b. Menyajikan data/informasi ke } \\
\text { representasi gambar, diagram, } \\
\text { grafik, atau tabel hampir } \\
\text { benar/mendekati benar } \\
\text { c. Menyajikan data/informasi ke } \\
\text { representasi gambar, diagram, } \\
\text { grafik, atau tabel benar }\end{array}$ & 2 \\
\hline $\begin{array}{l}\text { Menyelesaikan masalah } \\
\text { yang melibatkan ekspresi } \\
\text { matematis }\end{array}$ & $\begin{array}{l}\text { a. Menyelesaikan masalah yang } \\
\text { melibatkan eskpresi matematis } \\
\text { tetapi penyelesaian salah } \\
\text { b. Menyelesaikan masalah yang } \\
\text { melibatkan eskpresi matematis } \\
\text { tetapi penyelesaian kurang } \\
\text { benar } \\
\text { c. Menyelesaikan masalah yang } \\
\text { melibatkan eskpresi matematis } \\
\text { dengan benar }\end{array}$ & 1 \\
\hline $\begin{array}{l}\text { Menuliskan langkah- } \\
\text { langkah penyelesaian } \\
\text { masalah matematika } \\
\text { dengan kata-kata }\end{array}$ & $\begin{array}{l}\text { a. Hanya sedikit penjelasan (hanya } \\
\text { diketahui dan ditanya) } \\
\text { b. Penjelasan secara matematis } \\
\text { tetapi tidak tersusun secara } \\
\text { logis } \\
\text { c. Penjelasan secara matematis } \\
\text { dengan jelas dan tersusun } \\
\text { secara logis }\end{array}$ & 1 \\
\hline
\end{tabular}

Teknik analisis data yang dilakukan dalam penelitian ini terdiri dari tiga tahapan, yaitu reduksi data, menyajikan data, dan menarik kesimpulan. Pada tahap reduksi, peneliti merangkum kembali data hasil tes kemampuan representasi matematis yang kemudian diberi kode untuk memudahkan penulisan pada pemaparan data seperti "MA, NS, AP, MS, MK, dan WN". Data dikategorikan dan disajikan dalam bentuk teks yang bersifat naratif. Penarikan kesimpulan pada penelitian ini bertujuan 
untuk mendeskripsikan kemampuan representasi matematis siswa melalui pendekatan PMR.

\section{Temuan dan Pembahasan}

Pada bagian ini, akan disajikan dahulu data hasil penelitian berdasarkan hasil kerja MA, NS, AP, MS, MK, dan WN. Selanjutnya, hasil penelitian ini akan dibahas dan dibandingkan dengan kajian teori dan hasil penelitian sebelumnya yang relevan.

1. Kemampuan representasi matematis siswa MA

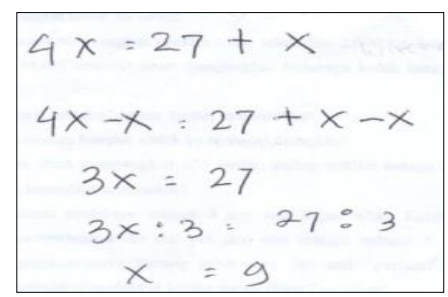

Gambar 1. Jawaban siswa MA pada soal PLSV

Pada jawaban di atas (Gambar 1) dapat dilihat bahwa Siswa MA dapat menghasilkan ide untuk soal persamaan ini dengan merepresentasikan soal tersebut kedalam model persamaan yang benar. Siswa MA dapat melakukan perhitungan aljabar untuk menentukan hasil dari persamaan yang dibuatnya dengan tepat.

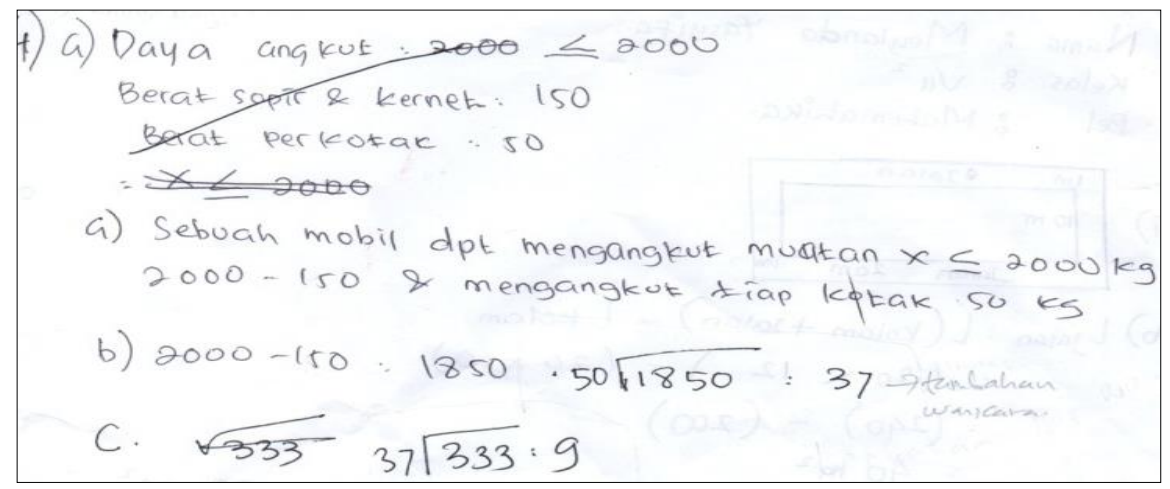

Gambar 2. Jawaban siswa MA Pada soal PtLSV 
Dari jawaban di atas (Gambar 2) dapat dilihat bahwa siswa MA dapat menyelesaikan soal PtLSV dengan menggunakan pertidaksamaan yang benar, siswa MA juga dapat melakukan perhitungan yang tepat.

Berdasarkan uraian di atas, kemampuan representasi matematis siswa MA memenuhi dua indikator yaitu menyelesaikan masalah yang melibatkan ekspresi matematis, serta menuliskan langkah-langkah penyelesaian masalah matematika dengan kata-kata.

2. Kemampuan representasi matematis siswa NS

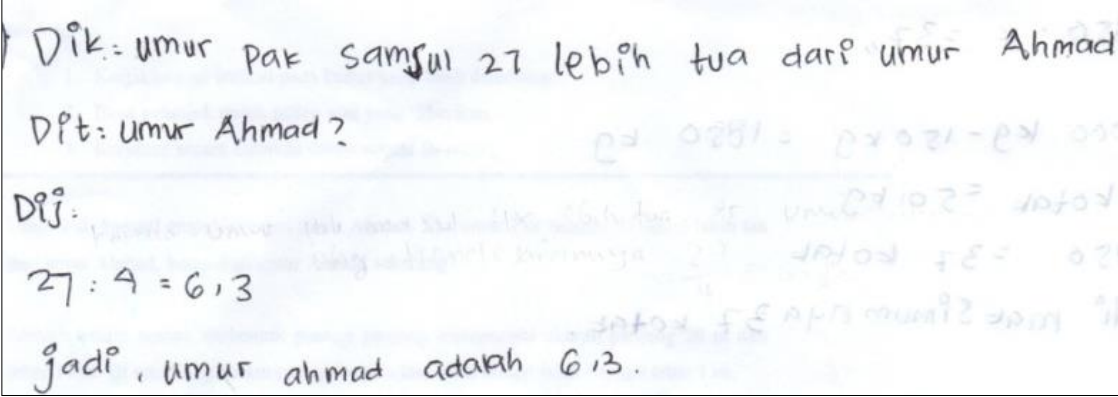

Gambar 3. Jawaban siswa NS Pada soal PLSV

Pada gambar di atas (Gambar 3) dapat dilihat bahwa siswa NS menjawab soal persamaan namun jawaban yang diberikan salah. Siswa NS tidak dapat merepresentasikan soal tersebut dengan benar.

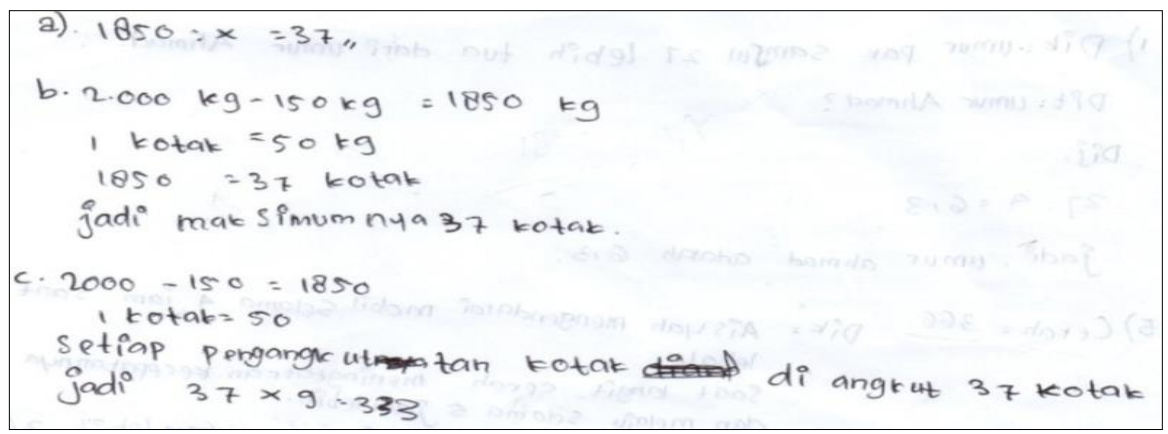

Gambar 4. Jawaban siswa NS Pada soal PtLSV

Dari gambar di atas (Gambar 4) dapat dilihat bahwa siswa NS dapat menyelesaikan soal PtLSV dengan menggunakan pertidaksamaan yang benar, siswa NS juga dapat melakukan perhitungan yang tepat. 
Pada Gambar 5 dapat dilihat bahwa Siswa NS dapat menghasilkan ide untuk soal perbandingan ini dengan merepresentasikan soal tersebut ke dalam tabel dengan benar, namun dia salah menggunakan konsep, siswa NS tidak dapat membedakan konsep dasar perbandingan berbalik nilai dengan perbandingan senilai, sehingga strategi penyelesaian yang digunakan salah, maka jawaban yang dihasilkan adalah tidak tepat.

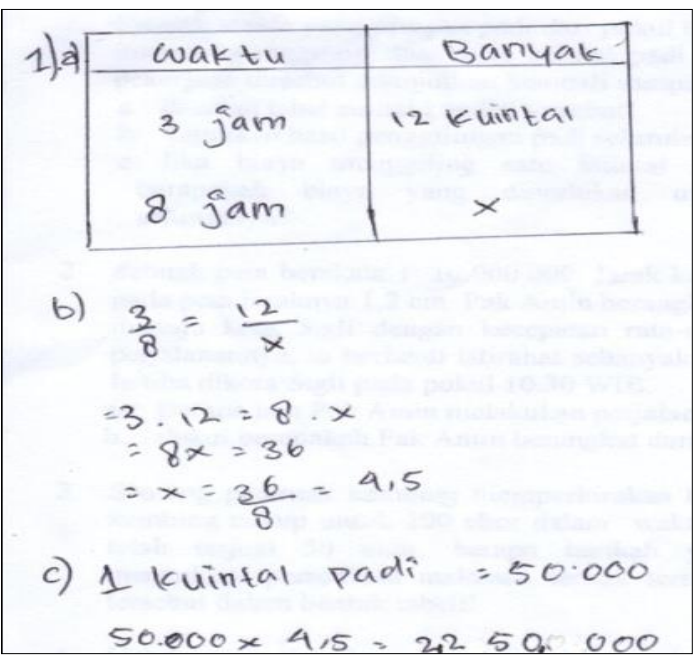

Gambar 5. Jawaban siswa NS Pada soal Perbandingan

Berdasarkan uraian di atas, kemampuan representasi matematis siswa NS hampir memenuhi dua indikator yaitu menyelesaikan masalah yang melibatkan ekspresi matematis, serta menuliskan langkah-langkah penyelesaian masalah matematika dengan kata-kata.

\section{Kemampuan representasi matematis siswa AP}

Dari Gambar 6 dapat dilihat bahwa siswa AP keliru ketika merepresentasikan soal PtLSV kedalam bentuk pertidaksamaan, meskipun prosedur penyelesaiannya jelas, serta dapat menyelesaikan masalah dengan perhitungan yang tepat. Namun ketika wawancara siswa AP mengubah tanda hubung pertidaksamaan sebelumnya dengan benar. 


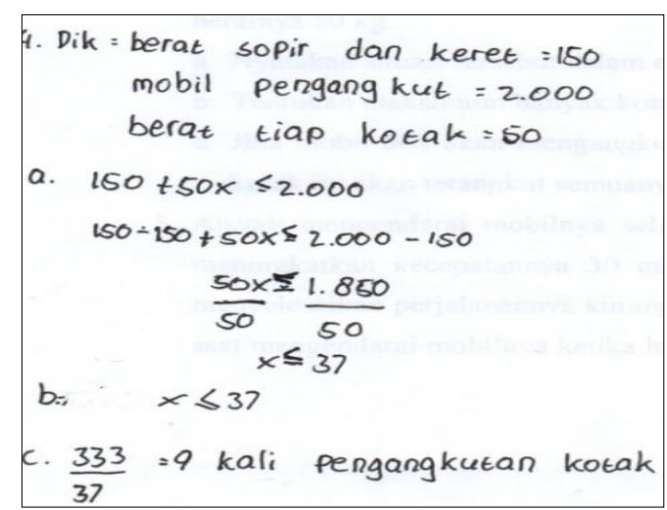

Gambar 6. Jawaban siswa AP pada soal PtLSV

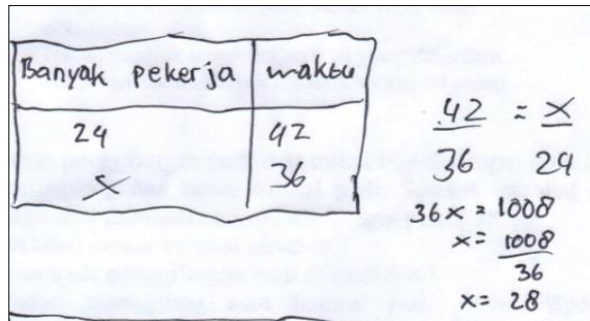

Gambar 7. Jawaban siswa AP pada soal perbandingan

Pada Gambar 7, siswa AP mempunyai ide dalam menyelesaikan soal perbandingan tersebut dengan merepresentasikan soal kedalam bentuk tabel, kemudian menggunakan konsep perbandingan berbalik nilai, namun jawaban yang diberikan tidak lengkap.

Berdasarkan uraian di atas, kemampuan representasi matematis siswa AP memenuhi ketiga indikator yaitu menyelesaikan masalah yang melibatkan ekspresi matematis, menyajikan data atau infomasi dari suatu masalah ke representasi grafik serta menuliskan langkah-langkah penyelesaian masalah matematika dengan kata-kata.

\section{Kemampuan representasi matematis siswa MS}

Dari Gambar 8 dapat dilihat bahwa siswa MS memiliki ide dalam menjawab soal PtLSV ini dengan merepresentasikan soal kedalam model matematika dengan tepat. Siswa MS memisalkan banyak kotak dengan $\mathrm{x}$. Sehingga persamaannya menjadi $150+50 x \leq 2000 \mathrm{~kg}$, pada soal nomor $3 b$ dan $3 c$ siswa MS menggunakan prosedur dalam menyelesaikan 
persamaan linear satu variabel dengan benar, siswa MS juga dapat melakukan perhitungan aljabar dengan tepat sehingga jawaban $b$ adalah 37 dan c adalah 9.

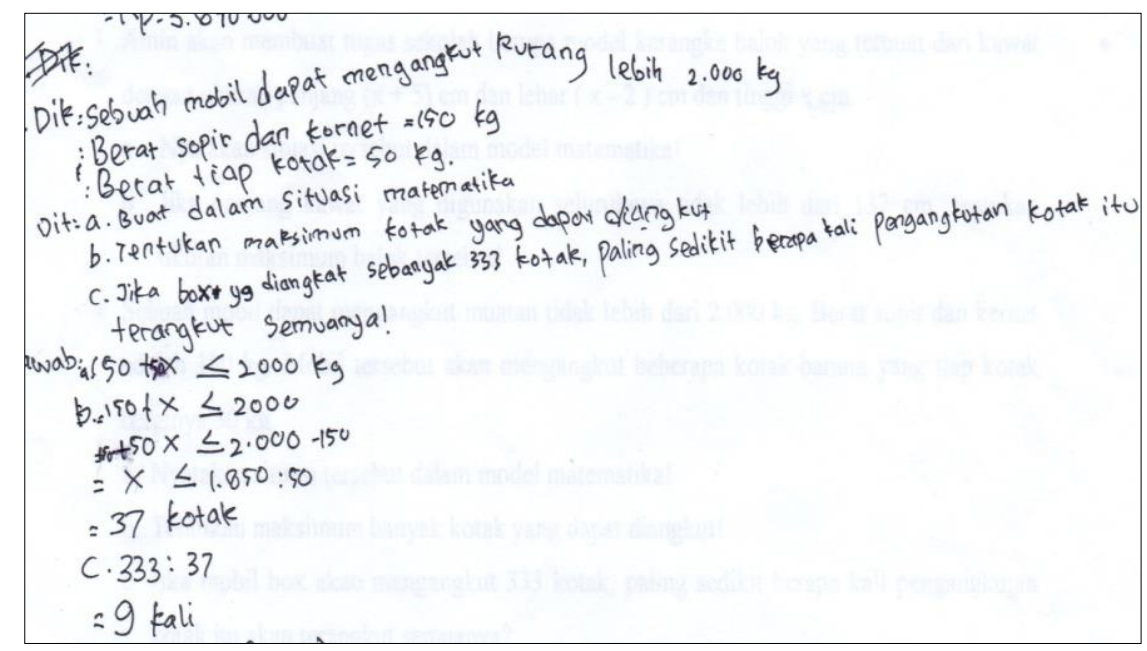

Gambar 8. Jawaban siswa MS pada soal PtLSV

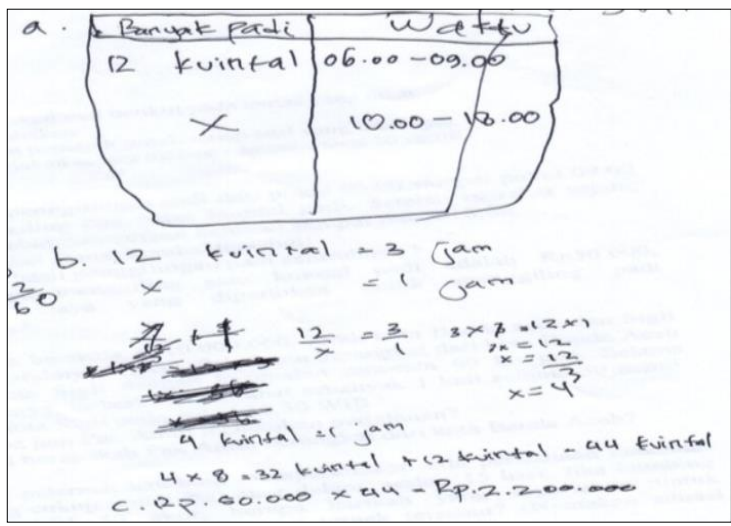

Gambar 9. Jawaban siswa MS pada soal Perbandingan

Pada Gambar 9 dapat dilihat bahwa siswa MS mempunyai ide dalam menyelesaikan soal perbandingan dengan benar. Siswa MS merepresentasikan soal kedalam bentuk tabel, kemudian menggunakan konsep perbandingan senilai, dan melakukan perhitungan dengan tepat.

Secara keseluruhan kemampuan representasi matematis siswa MS memenuhi ketiga indikator yaitu menyelesaikan masalah yang melibatkan ekspresi matematis, menyajikan data atau infomasi dari suatu masalah ke 
representasi tabel serta menuliskan langkah-langkah penyelesaian masalah matematika dengan kata-kata.

5. Kemampuan representasi matematis siswa MK

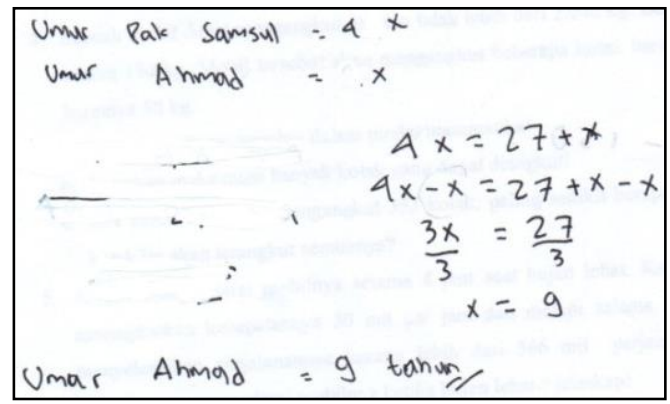

Gambar 10. Jawaban siswa MK pada soal PLSV

Pada Gambar 10 dapat dilihat bahwa siswa MK dapat menghasilkan ide untuk soal persamaan ini dengan merepresentasikan soal tersebut kedalam model persamaan yang benar. Siswa MA dapat melakukan perhitungan aljabar untuk menentukan hasil dari persamaan yang dibuatnya dengan tepat.

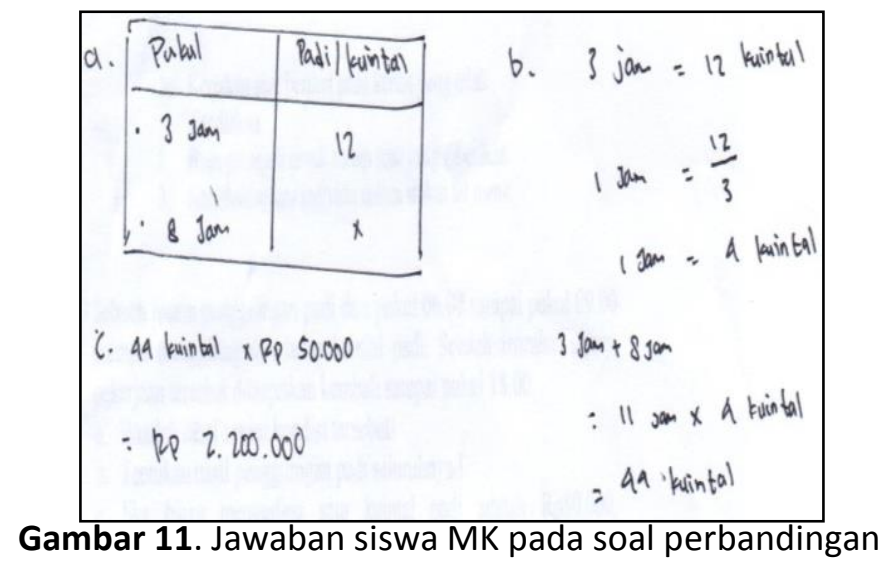

Pada Gambar 11 siswa MK mengerti konsep apa yang digunakan dalam menyelesaikan soal perbandingan ini dengan mengisi tabel dengan tepat, kemudian menggunakan konsep perbandingan senilai, prosedur yang digunakan dalam meyelesaikan persamaannya pun tepat sehingga perhitungan dan langkah-langkah penyelesaiannya benar. 


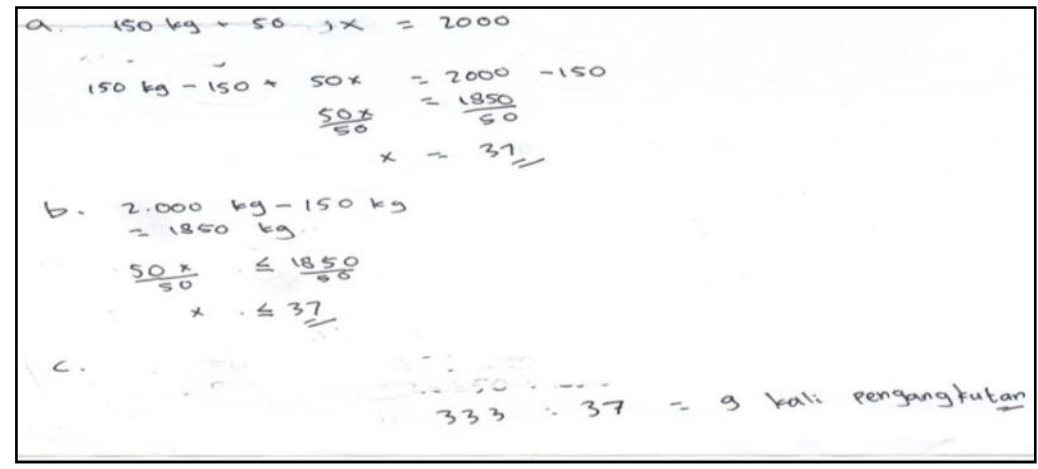

Gambar 12. Jawaban siswa MK pada soal PtLSV

Pada Gambar 12 dapat dilihat bahwa siswa MK dapat menyelesaikan soal PtLSV dengan menggunakan pertidaksamaan yang benar, siswa MK juga dapat melakukan perhitungan yang tepat.

Berdasarkan uraian jawaban siswa MK, siswa tersebut dapat menjawab semua soal dengan benar. Ini artinya, siswa MK telah memenuhi semua indikator kemampuan representasi matematis yaitu menyajikan data atau informasi dari suatu masalah ke representasi tabel, menyelesaikan masalah yang melibatkan ekspresi matematis, serta menuliskan langkah-langkah penyelesaian masalah matematika dengan kata-kata.

6. Kemampuan representasi matematis siswa $\mathrm{WN}$

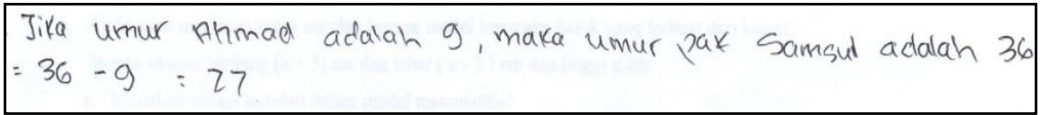

Gambar 13. Jawaban siswa WN pada soal PLSV

Dari jawaban siswa WN (Gambar 13) dapat dilihat bahwa siswa WN menjawab soal tersebut dengan substitusi. Dia memahami maksud dari soal tetapi tidak mengubah soal tersebut kedalam bentuk PLSV. Strategi yang digunakan dalam mencari umur Ahmad adalah dengan mencari angka yang perbedaannya 27 tetapi juga dari perkalian 4. Karena 9 dikali 4 hasilnya 36 dan jika 36 dikurangkan dengan 9 hasilnya 27, jadi umur Ahmad adalah 9 tahun. 


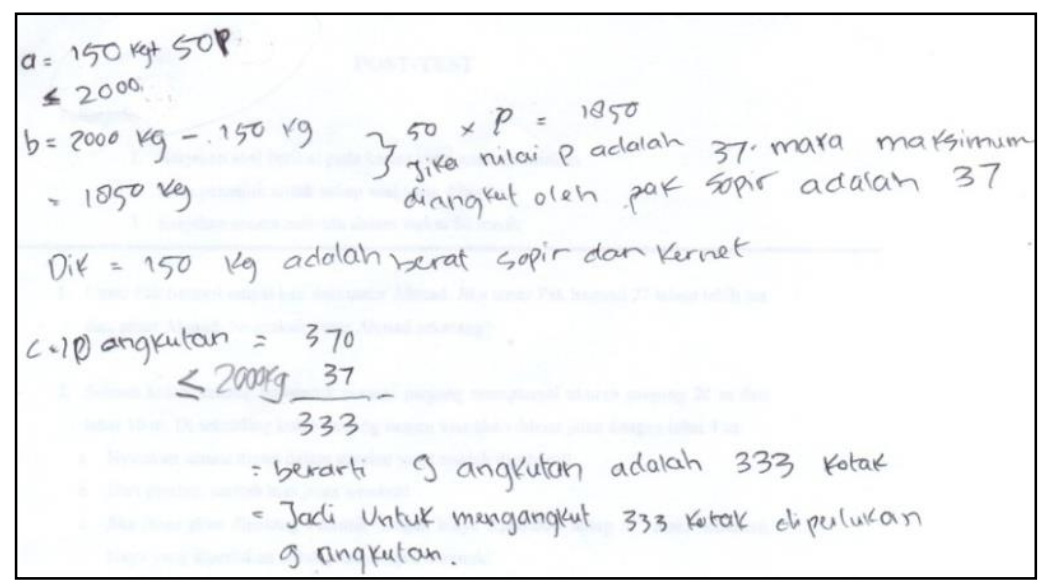

Gambar 14. Jawaban siswa WN pada soal PtLSV

Siswa WN (Gambar 14) dapat menyelesaikan soal PtLSV dengan menggunakan pertidaksamaan yang benar, siswa WN juga dapat melakukan perhitungan yang tepat.

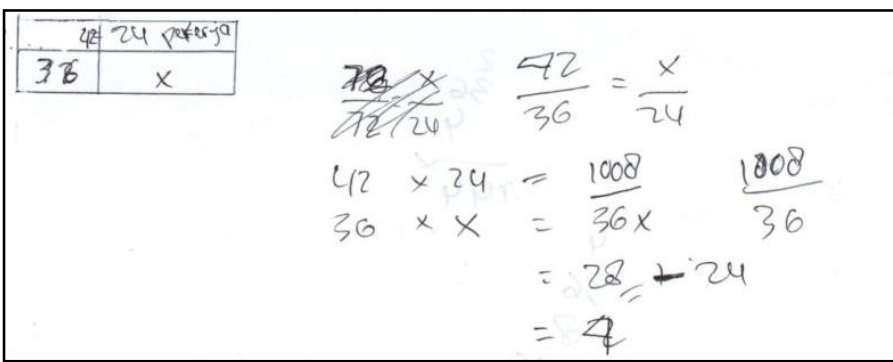

Gambar 15. Jawaban siswa WN pada soal Perbandingan

Siswa WN (Gambar 15) mengerti konsep apa yang digunakan dalam menyelesaikan soal perbandingan ini dengan mengisi tabel dengan tepat, kemudian menggunakan konsep perbandingan senilai, prosedur yang digunakan dalam meyelesaikan persamaannya pun tepat sehingga perhitungan dan langkah-langkah penyelesaiannya benar.

Berdasarkan uraian jawaban siswa WN, siswa tersebut dapat menjawab semua soal dengan benar. Ini artinya, siswa WN telah memenuhi semua indikator kemampuan representasi matematis yaitu menyajikan data atau informasi dari suatu masalah ke representasi tabel, menyelesaikan masalah yang melibatkan ekspresi matematis, serta 
menuliskan langkah-langkah penyelesaian masalah matematika dengan kata-kata.

Hasil analisis data setiap siswa menunjukan kemampuan representasi matematis siswa pada setiap pertemuan dengan materi PLSV, PtLSV dan perbandingan mencapai kategori baik karena bisa memenuhi semua dan beberapa indikator (Tabel 1). Kemampuan representasi siswa yang berkemampuan tinggi dan sedang telah memenuhi ketiga indikator kemampuan representasi. Ketiga indikator tersebut yaitu menyajikan data atau informasi dari suatu masalah ke representasi tabel, menyelesaikan masalah yang melibatkan ekspresi matematis, serta menuliskan langkahlangkah penyelesaian masalah matematika dengan kata-kata.

Siswa yang berkemampuan tinggi dan sedang memahami permasalahan yang diberikan, mampu merepresentasikan masalah yang diberikan kedalam bentuk matematis, mampu mengkomunikasikan penyelesaian masalah serta tepat dalam melakukan perhitungan. Sedangkan kemampuan representasi siswa yang berkemampuan rendah, MA memenuhi dua indikator dan siswa NS memenuhi satu indikator dari kemampuan representasi. Siswa yang berkemampuan rendah mengalami kesulitan dalam memahami permasalahan yang diberikan, kesulitan merepresentasikan masalah yang diberikan kedalam bentuk matematis, sehingga prosedur penyelesaian yang dibuat tidak jelas dan keliru dalam melakukan perhitungan.

Kemampuan representasi matematika MK, WN, AP dan MS yang berada pada kategori baik didukung oleh beberapa hal. Diantaranya siswa berkemampuan tinggi ( $M K$ dan WN) dan siswa berkemampuan sedang (AP dan MS) pada proses pembelajaran aktif dan senang belajar kelompok atau berpasangan sedangkan siswa berkemampuan rendah (MA dan NS) cenderung tidak aktif dan bekerja sendiri.

Lemahnya kemampuan representasi matematis siswa ini sejalan dengan yang disampaikan Pujiastuti (2008) yang menemukan bahwa sebagian besar siswa masih lemah dalam menyampaikan ide melalui lisan atau teks tertulis. Penjelasan tersebut memberikan penguatan bagi hasil penelitian ini bahwa representasi yang tidak tepat menyebabkan kesalahan dalam penyelesaian masalah, misalnya ketika mengubah soal cerita kedalam model matematis. 
Representasi yang dikembangkan oleh MK, WN, AP dan MS memudahkan mereka untuk aktif menyampaikan pemikirannya kepada siswa lain dalam diskusi kelompok. Sedangkan, untuk MA dan NS lebih banyak bekerja sendiri. Keadaan tersebut sesuai dengan NCTM (2000), representasi membantu siswa menyampaikan pemikirannya kepada siswa lain. Keaktifan MK, WN, AP dan MS juga didukung oleh keseriusan mereka dalam pembelajaran. Mereka mengetahui kaitan materi yang diajarkan dalam kehidupan sehari-hari. Siswa MK, WN, AP dan MS termotivasi dengan pembelajaran yang mengaitkan materi PLSV, PtLSV dan perbandingan dengan permasalahan realistik. Treffers (Wijaya, 2012) menyatakan bahwa mengaitkan materi dengan permasalahan realistik dapat meningkatkan motivasi dan ketertarikan siswa dalam belajar matematika sehingga siswa mempunyai keinginan untuk belajar, serta akan belajar lebih banyak.

MK, WN, AP dan MS mampu mengaitkan materi yang dipelajari dengan pengetahuan sebelumnya. Berdasarkan jawaban pada tes siswa, MK dan WN dapat merepresentasikan soal dengan tepat, dimana materi yang dipelajari merupakan lanjutan dari materi sebelumnya. Dapat dikatakan MK, WN, AP, MS telah belajar secara bermakna, mengaitkan materi konsep PLSV, PtLSV dan perbandingan. Hal ini sejalan dengan pendapat Freudental (1991), proses belajar siswa hanya akan terjadi jika pengetahuan yang dipelajari memiliki makna bagi siswa. Hal ini juga sesuai teori Ausubel (Nur, 2011), belajar bermakna terjadi jika siswa mampu mengaitkan materi yang dipelajari dengan pengetahuan sebelumnya yang ada dalam struktur kognitifnya.

MK, WN, MS dan AP memanfaatkan dengan sebaiknya-baiknya media yang diberikan guru untuk menyelesaikan tugas kelompok. Media yang dibagikan berupa LKPD (Lembar Kegiatan Peserta Didik) yang berisikan permasalahan realistik (konteks). Pemanfaatan LKPD yang berisikan permasalahan realistik (konteks) sesuai dengan pendapat Treffers (Wijaya, 2012) bahwa konteks atau permasalahan realistik digunakan sebagai titik awal pembelajaran matematika.

Ketika proses pembelajaran berlangsung $\mathrm{MK}, \mathrm{WN}, \mathrm{MS}$ dan AP menunjukkan rasa percaya diri, mereka tampak akrab dengan teman sekelompoknya, aktif bekerja berpasangan mengerjakan LKPD, tukar pendapat dengan pasangannya. Keadaan tersebut sesuai dengan 
pendapat Hadi (2017) bahwa dalam pendidikan matematika realistik siswa harus lebih percaya diri. Sejalan dengan itu, Treffers (Wijaya, 2012) menekankan pentingnya interaksi sosial dengan orang lain. Proses belajar siswa akan menjadi lebih singkat dan bermakna ketika siswa saling mengkomunikasikan hasil kerja dan gagasan mereka. Pemanfaatan interaksi dalam pembelajaran matematika bermanfaat dalam mengembangkan kemampuan kognitif dan afektif siswa secara simultan. Sejalan dengan teori Vygotsky (Nur, 2011) yang menekankan penting interaksi sosial dengan orang lain terlebih yang punya pengetahuan lebih baik dan sistem yang secara kultural telah berkembang dengan baik.

Representasi yang dibuat siswa melalui tahap menyelesaikan masalah, mendukung siswa untuk membangun pemahaman materi PLSV, PtLSV dan perbandingan. Representasi memudahkan siswa mengkomunikasikan pemahamannya dalam diskusi. Hal ini didukung oleh Anita (2004) bahwa representasi membantu siswa mengkonstruk pemahaman dengan penalarannya, yang kemudian mengkomunikasikan serta mendemonstrasikan penalarannya.

Masalah yang diberikan kepada siswa adalah masalah realistik yang berkaitan dengan kehidupan sehari-hari. Masalah realistik tersebut relevan dengan taraf berpikir siswa dan sesuai dengan konteks kehidupan siswa. Hal ini didukung oleh Hadi (2017) bahwa masalah kontekstual yang diberikan harus memenuhi syarat relevansi dan familiaritas, yaitu relevan dengan taraf berpikir siswa dan sudah dikenal siswa karena diambil dari konteks kehidupan siswa.

Kemampuan representasi matematika secara keseluruhan mencapai kategori baik. Beberapa siswa, termasuk MK, WN, AP dan MS mampu menyajikan informasi dari suatu masalah ke representasi tabel. Hal ini dapat dilihat pada hasil tes siswa dalam mengerjakan permasalahan perbandingan. Siswa tersebut memutuskan bahwa mereka perlu menggunakan gambar dan tabel dalam membantu menyelesaikan soal. Keadaan ini sesuai dengan Rosengrant, Etkina dan Van Heuvelen (2005), yang menyatakan bahwa beberapa representasi bersifat lebih konkrit dan berfungsi sebagai acuan untuk konsep-konsep yang lebih abstrak dan sebagai alat bantu dalam pemecahan masalah.

Pada saat bekerja untuk menyelesaikan soal realistik materi PLSV siswa melewati dua bentuk matematisasi, yaitu matematisasi horizontal 
dan vertikal. Matematisasi horizontal terjadi ketika siswa mengerjakan LKPD PLSV, pada LKPD tersebut diberikan gambar timbangan dimana ada tiga beban yang berbentuk bola dan enam koin seimbang dengan dua belas koin. Untuk menentukan berat sebuah bola yaitu dengan cara mengambil enam koin di kedua lengan, sehingga tiga bola setara dengan enam koin, kemudian membagi koin menjadi tiga bagian yang sama sehingga diperoleh 1 bola setara dengan dua koin. LKPD tersebut berisi tentang konsep dasar PLSV. Selanjutnya, siswa diperhadapkan dengan soal/masalah konsep PLSV dengan langsung melakukan perhitungan secara matematis ketika itulah sedang terjadi pematematikaan vertikal. Matematisasi horizontal dan vertikal yang dilakukan oleh siswa pada dasarnya merupakan suatu re-invention. Siswa dibawa pada suatu situasi dimana siswa menemukan cara menyelesaikan PLSV, PtLSV dan perbandingan.

Pembelajaran melalui PMR dapat mendukung siswa menciptakan dan menggunakan representasi matematika siswa pada materi PLSV, PtLSV dan perbandingan baik dengan cara memodelkan secara matematis, merepresentasikan permasalahan dalam bentuk tabel. Siswa dengan mudah memahami materi PLSV, PtLSV dan perbandingan. Keadaan ini sesuai dengan Treffers (Wijaya, 2012) dalam PMR, model digunakan dalam melakukan matematisasi secara progresif. Penggunaan model berfungsi sebagai jembatan dari pengetahuan dan matematika tingkat konkrit menuju pengetahuan matematika tingkat formal. Hal ini juga sejalan dengan pendapat Gravemeijer (1994) model yang dikembangkan sendiridalam memecahkan masalah kontekstual, siswa diberi kesempatan untuk mengembangkan model mereka sendiri. Pengembangan model ini dapat berperan dalam menjembatani pengetahuan informal dan pengetahuan formal serta konkret dan abstrak.

\section{Simpulan}

Berdasarkan hasil penelitian dan pembahasan tentang kemampuan representasi matematis siswa melalui pendekatan PMR, maka diperoleh kesimpulan bahwa siswa yang berkemampuan tinggi dan sedang memenuhi ketiga indikator kemampuan representasi matematis yaitu menyajikan data atau informasi dari suatu masalah ke representasi tabel, menyelesaikan masalah yang melibatkan ekspresi matematis, serta 
menuliskan langkah-langkah penyelesaian masalah matematika dengan kata-kata. Siswa berkemampuan rendah memenuhi dua indikator kemampuan representasi matematis yaitu menyelesaikan masalah yang melibatkan ekspresi matematis dan menuliskan langkah-langkah penyelesaian masalah matematika dengan kata-kata.

\section{Daftar Pustaka}

Anita, I.W. (2014). Pengaruh pembelajaran matematika realistik berbasis kurikulum 2013 terhadap peningkatan kemampuan representasi matematik siswa SMP. Prosiding Seminar Nasional Pendidikan Matematika, Bandung, 295-298.

Dahlan, J. A. (2011). Materi pokok analisis kurikulum matematika. Jakarta: Universitas Terbuka.

Freudenthal, H. (1991). Revisiting mathematics education. Dordrecht: Kluwer Acaemic Publishers.

Gravemeijer, K.P.E. (1994). Developing realistic mathematics education. Technipress: Culemborg, the Netherlands.

Hadi, S. (2017). Pendidikan matematika realistik: Teori, pengembangan dan implementasinya. Jakarta: Rajawali Pers.

Kohar, A.W (2012) Desain pembelajaran PMRI 5: "Butuh berapa kotak kue lagi agar kardus itu penuh?" (Deskripsi Pembelajaran Volume Balok dan Kubus di Kelas 5C SD N 1 Palembang) IMPoME 2012, 5th Observation Report of Classroom Observation.

Legi, M. Y. (2008). Kemampuan representasi matematis siswa SD kelas IV melalui pendidikan matematika realistik pada konsep pecahan dan pecahan senilai. Diakses di http://karyailmiah.um.ac.id/index.php/disertasi/article/view/899

NCTM. (2000). Principles and standards for school mathematics. USA: Association Drive, Reston.

Nur, M. (2011). Model pembelajaran berdasarkan masalah. Surabaya: UNESA. OECD. (2014). PISA 2012 results: What students know and can do. Student performance in mathematics reading and science (Volume I, Revised Edition, February 2014). PISA, OECD Publishing.

Pujiastuti, H. (2008). Pembelajaran kontekstual untuk meningkatkan kemampuan koneksi dan representasi siswa SMP. Tesis SPS UPI Bandung.

Rosengrant, D., Etkina, E., \& Van Heuvelen, A. (2005). An overview of recent research on multiple representations. Diakses di http://paer.rutgers.edu/ScientificAbilities/Downloads/Papers/DavidRospe rc2006.pdf. 
Soedjadi, R. (2007). Inti dasar-dasar pendidikan matematika realistik indonesia. Jurnal Pendidikan Matematika. 1(2), 125-133.

Suryowati, E. (2015). Kesalahan siswa sekolah dasar dalam merepresentasikan pecahan pada garis bilangan. Aksioma Jurnal Pendidikan Matematika, 4 (1), 38-52.

TIMSS. (2011). TIMSS 2011 International result in mathematics. Chestnut Hill: TIMSS dan PIRLS International Study Center.

Wijaya, A (2012). Pendidikan matematika realistik: Suatu alternatif pendekatan pembelajaran matematika. Yogyakarta: Graha IImu. 